\title{
Pemanfaatan Panas Buang Air Conditioner (AC) pada Lemari Pengering Benih Padi
}

\author{
Bachtera Indarto,* Santi Puspitasari, dan Hasto Sunarno \\ Departemen Fisika-FMIPA, Institut Teknologi Sepuluh Nopember Kampus ITS Sukolilo, Surabaya, 60111
}

\begin{abstract}
Intisari
Penelitian mengenai pemanfaatan panas buang air conditioner (AC) pada lemari pengering benih padi telah berhasil dilakukan. Penelitian ini bertujuan untuk mendapatkan rancangbangun lemari pengering padi dengan memanfaatkan panas buang dari kondensor AC serta mengatur temperatur dan kelembaban udara di dalam lemari pengering sesuai dengan ketentuan dalam proses pengeringan benih padi. Lemari pengering yang dibuat berjenis tray dryer, memiliki 4 rak dan terbuat dari kayu triplek berlapis aluminium foil berdimensi $50 \mathrm{~cm} \times 50$ $\mathrm{cm} \times 60 \mathrm{~cm}$ dengan kapasitas $2 \mathrm{~kg}$. Pengaturan temperatur dan kelembaban udara lemari pengering dirancang dengan menggunakan sensor SHT 11. Sistem ini menghasilkan benih padi dengan kadar air $11 \%$ setelah proses pengeringan selama 10 jam. Pengaturan temperatur menggunakan kipas exhaust bekerja dengan baik selama proses pengeringan yang diatur pada rentang $30-43^{\circ} \mathrm{C}$, sedangkan pengaturan kelembaban udara menggunakan blower dapat dipertahankan dengan nilai di atas $42,55 \%$.
\end{abstract}

\begin{abstract}
Research on the utilization of heat exhaust from the air conditioner (AC) for paddy dryer cupboard, has been successfully done. The objective of this research is to get the design of rice dryer cabinets by utilizing the exhaust heat from the air conditioner condenser and adjust the temperature and humidity of the air in the drying cabinet in accordance with the provision in the drying process of rice seed. Dryer cabinet made of the type of tray dryer has 4 shelves and made of wood plywood plated aluminum foil dimension $50 \mathrm{~cm} \times 50 \mathrm{~cm} \times 60 \mathrm{~cm}$ with a capacity of $2 \mathrm{~kg}$. The temperature and humidity settings of the drying cabinet are designed using SHT 11. This system produces rice seeds with the moisture content of $11 \%$ after 10 hours of the drying process. The temperature setting using exhaust fan works well during the drying process which is set at $30-43^{\circ} \mathrm{C}$, while the air humidity setting using blower can be maintained at a value above $42.55 \%$.
\end{abstract}

KATA KUNCI: riceseed, exhaust, SHT 11

http://dx.doi.org/10.12962/j24604682.v13i3.3101

\section{PENDAHULUAN}

Indonesia merupakan negara agraris dengan jumlah total areal lahan persawahan baku mencapai 8,1 juta hektar pada tahun 2014 lalu. Sebagian besar penduduknya bermata pencaharian sebagai petani. Berdasarkan data BPS, penyerapan tenaga kerja pada sektor pertanian lebih besar dibandingkan sektor lainnya yaitu sebesar 34,4 persen dari 38,07 juta penyerapan tenaga kerja di Indonesia. Padi merupakan jenis tanaman yang paling sering dipilih para petani di pulau Jawa. Hal ini dikarenakan padi atau beras adalah salah satu sumber makanan pokok bagi orang Indonesia pada umumnya.

Benih padi yang baik diperoleh setelah melalui beberapa proses. Salah satu proses penting setelah masa panen berlalu yakni tahap pengeringan. Pengeringan secara tradisional yakni dijemur di bawah sinar matahari selama 12 jam dan dilakukan pembalikan setiap 2 jam agar padi kering merata. Ketebalan tumpukan padi yang disarankan sebesar 3-6 cm. Luas lahan pengeringan yang diperlukan dapat mencapai $150 \mathrm{~m}^{2} /$ ton padi [1]. Di sisi lain penggu-

*E-MAIL: bachtera@physics.its.ac.id naan mesin pendingin ruangan (air conditioner $(\mathrm{AC})$ ) pada rumah tangga, institusi pendidikan dan instansi-instansi lain yang semakin banyak menghasilkan panas buang yang makin berlimpah. Pemanfaatan panas buang AC yang masih sangat minim menyebabkan energi panas terbuang sia-sia. Panas yang dihasilkan oleh saluran pembuangan AC dapat mencapai temperatur $40^{\circ} \mathrm{C}$. Temperatur udara tersebut dapat digunakan untuk pemanasan dalam proses pengeringan bahan makanan.

Pada prinsipnya, pengeringan memiliki tujuan utama untuk mengurangi kadar air yang terkandung pada bahan sampai pada kadar air yang diinginkan. Dengan mengurangi kadar air ke tingkat yang cukup rendah pada suatu produk atau bahan olahan dapat menghambat pertumbuhan mikroorganisme, reaksi enzimatik, dan reaksi lainnya yang dapat merusak produk atau bahan tersebut. Kadar air produk atau bahan yang rendah dapat memperpanjang daya simpan produk atau bahan. Faktor-faktor yang berpengaruh dalam proses pengeringan adalah temperatur, kelembaban udara, laju aliran udara, kadar air awal bahan dan kadar air akhir bahan [2] .

Pengeringan benih padi dengan mesin pengering, harus memperhatikan pengaturan temperatur yang mencapai permukaan benih sesuai kadar air awal benih. Bila kadar awal benih di atas $25 \%$, maka temperatur pengeringan dapat diatur diatas $35^{\circ} \mathrm{C}$ dan bila kadar air awal di bawah $25 \%$ maka 
TABEL I: Spesifikasi persyaratan mutu di laboratorium [4].

\begin{tabular}{lc}
\hline \hline Jenis analisis & \multicolumn{1}{c}{ Persyaratan } \\
\hline Kadar air (bb) & Maksimum 13,0\% \\
Biji benih tanaman lain & $0,0 \%$ \\
Benih murni & Minimum 99,0\% \\
Daya kecambah/dayatumbuh & Minimum 80,0\% \\
Kotoran benih & Maksimum 1,0\% \\
\hline \hline
\end{tabular}

temperatur pengeringan dapat dinaikkan secara bertahap sampai maksimum mencapai temperatur $45^{\circ} \mathrm{C}$. Makin rendah kadar air yang dimiliki oleh benih maka makin tinggi pula temperatur yang dapat diterapkan selama proses pengeringan berlangsung dalam rentang temperatur yang aman yakni 30$45^{\circ} \mathrm{C}$. Kadar air akhir yang diharapkan untuk benih padi ialah $10-12 \%$. Benih padi dengan kadar air $11 \%$ memungkinkan penyimpanan dalam temperatur kamar selama satu tahun, atau dengan kadar air 9\% untuk penyimpanan lebih lama yang mungkin diperlukan untuk benih. Angka kadar air yang dimiliki benih mempengaruhi kepekaan benih terhadap kerusakan mekanik, semakin kecil kadar air benih akan menambah kepekaan benih terhadap kerusakan mekanis [3]. Spesifikasi persyaratan mutu di laboratorium ditunjukkan dalam Tabel I.

Kadar air benih ialah berat air yang terkandung dan dinyatakan dalam persentase terhadap berat awal contoh benih. Penentuan kadar air pada suatu tingkatan tertentu setelah pengeringan sangat penting agar benih dalam keadaan yang cocok untuk disimpan [5].

Air dalam suatu bahan makanan terdapat dalam berbagai bentuk, yaitu:

- Air bebas, terdapat dalam ruang antar sel dan inter granular dan pori-pori yang terdapat pada bahan.

- Air yang terikat secara lemah karena terserap pada permukaaan koloid makromolekuler seperti protein, pectin pati, selulosa. Selain itu air juga terdispersi diantara koloid tersebut dan merupakan pelarut zat- zat yang ada dalam sel. Air yang ada dalam bentuk ini masih tetap mempunyai sifat air bebas dan dapat dikristalkan pada proses pembekuan. Ikatan antara air dan koloid tersebut merupakan ikatan hidrogen.

- Air dalam keadaan terikat kuat yaitu membentuk hidrat. Ikatannya bersifat ionik sehingga relatif sukar dihilangkan atau diuapkan. Air ini tidak membeku meskipun pada $0^{\circ} \mathrm{F}[6]$.

Dalam proses pengeringan dengan mesin diperlukan sebuah sistem yang dapat bekerja secara otomatis. Penga-turan temperatur dan kelemaban udara lemari pengering dirancang dengan menggunakan SHT 11, seperti ditunjukkan pada Gambar 1. Modul sensor SHT 11 merupakan sensor produksi Sensirion Corp. di Zurich, Switzerland. Sensor ini telah beredar dipasaran sejak Februari 2002 dan telah diakui sebagai sensor yang sangat handal. Sensor SHT 11 berbentuk chip dan dapat digunakan sebagai sensor temperatur dan kelembaban relatif tunggal dengan keluaran digital terkalibrasi melalui antarmuka serial dua kawat (2-wire serial interface) yang mudah

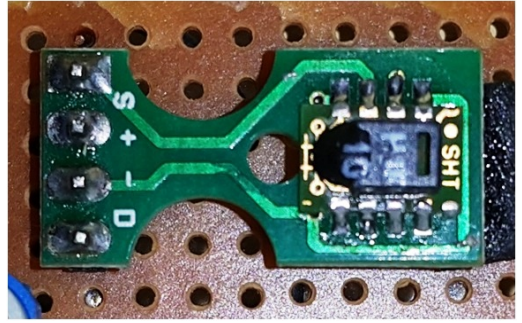

Gambar 1: Sensor SHT 11.

dihubungkan kemikrokontroler, sehingga sangat hemat terhadap jalur masukan/keluaran (I/O) kontroler. Rentang pengukuran sensor ini yakni dari $-40-123,8^{\circ} \mathrm{C}, 0-100 \% \mathrm{RH}$ dengan akurasi absolut dim $3 \%$ pada saat pengukuran kelembaban $20 \%-80 \%$, sedangkan akurasi pengukuran temperatur $\pm 0,4^{\circ} \mathrm{C}$ pada temperatur $25^{\circ} \mathrm{C}$.

Karakteristik lain dari sensor SHT 11 yaitu mempunyai stabilitas jangka panjang yang sempurna, konsumsi daya sangat rendah (sekitar 30 mikrowatt), tidak memerlukan peranti luar tambahan, kemudahan dalam pemasangan, berukuran kecil, dan mudah dipasang atau dihubungkan [7].

Sistem kerja sensor berdasarkan prinsip kapasitif dan bandgap. Uap air sebagai bahan dielektrikum akan masuk diantara elektroda berupa lapisan polimer yang terdapat dalam sensor. Sehingga sensor ini dapat digunakan sebagai sensor kelembaban kapasitif. Difusi dari bahan kimia ke dalam sebuah polimer menyebabkan pergeseran nilai kapasitif dan menyebabkan sensitifitas. Dari perubahan nilai kapasitif terhadap bahan polimer pada sensor akan dirubah kebesaran tegangan dan juga mengubahnya dalam bentuk data digital 12 bit untuk kelembaban. Bandgap adalah selisih energi minimum dari pita konduksi dan energi maksimum dari pita valensi.

Elektron pada pita konduksi dapat berkombinasi secara langsung dengan hole pada pita valensi maksimum. Energi yang saling berkombinasi menyebabkan timbulnya emisi yang diwujudkan dalam bentuk tegangan. Apabila bandgap diberikan temperatur yang tinggi maka emisi yang terjadi semakin meningkat [8].

\section{METODE PENELITIAN}

Langkah awal dalam penelitian ini yaitu menyiapkan alat dan bahan yaitu sensor SHT11, Arduino Uno, LCD $20 \times 4$, grain moisture meter tipe MD7822, kondensor AC $\frac{3}{4} \mathrm{pk}$, adaptor $12 \mathrm{~V} / 1000 \mathrm{~mA}$, kipas DC, timbangan digital, pcb matrix, resistor variabel $50 \mathrm{k} \Omega$, kabel, papan triplek (6 mm), alumunium foil, kawat kasa, benih padi jenis ciheras.

Penelitian ini terdiri dari dua sistem yaitu sistem perangkat keras dan sistem perangkat lunak, seperti ditunjukkan Gambar 2. Sistem perangkat keras meliputi kondensor AC sebagai sumber panas, lemari pengering berjenis tray dryer (rak bersusun), rangkaian sensor temperatur dan kelembaban udara dilengkapi dengan mikrokontroler Arduino Uno sebagai perangkat kendali, rangkaian relay sebagai saklar otoma- 


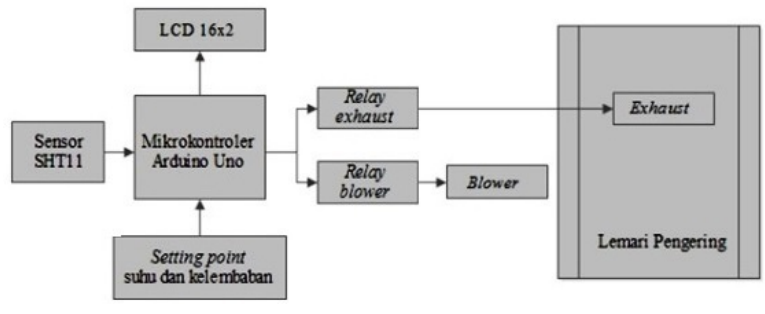

Gambar 2: Gambaran umum sistem.

tis untuk exhaust dan blower, dan rangkaian LCD graphic untuk menampilkan hasil pengukuran. Sistem perangkat lunak terdiri dari perancangan program dengan menggunakan perangkat lunak Arduino Ide yang berisi perintah-perintah untuk mengatur dan menampilkan hasil pengukuran kondisi di dalam lemari pengering, meliputi temperatur dan kelembaban udara.

\section{Perancangan perangkat keras}

Pada tahap ini akan dijelaskan tentang perancangan dan pembuatan perangkat keras meliputi lemari pengering berjenis tray dryer (rak bersusun), rangkaian sensor temperatur dan kelembaban udara dilengkapi dengan mikrokontroler Arduino Uno sebagai perangkat kendali, rangkaian relay sebagai saklar otomatis untuk exhaust dan blower, dan rangkaian LCD graphic untuk menampilkan hasil pengukuran.

\section{Pembuatan lemari pengering}

Pada penelitian ini, metode pengeringan yang digunakan ialah metode pengeringan dengan menggunakan mesin berjenis tray dryer. Lemari pengering jenis tray dryer ini dirancang berbentuk rak bersusun yang terdiri dari 4 rak dan jarak antar rak sebesar $12 \mathrm{~cm}$. Rangka dan sisi-sisi pada lemari terbuat dari kayu dan triplek dengan dimensi $50 \mathrm{~cm} \times 50 \mathrm{~cm} \times 60$ $\mathrm{cm}$. Pada salah satu sisi lemari sengaja diberi lubang dengan ukuran yang disesuaikan dengan lebar kipas kondensor AC yang digunakan. Tujuannya ialah untuk mengalirkan udara panas sebagai media pengering langsung menuju rak-rak yang berisi tupukan benih. Rak yang diletakkan di dalam lemari terbuat dari kawat kasa yang memiliki ukuran lubang kecil agar buiran benih padi tidak mudah jatuh.

\section{Pembuatan rangkaian sensor temperatur dan kelembaban udara}

Selama proses pengeringan berlangsung diperlukan sebuah sensor yang digunakan untuk mengamati temperatur dan kelembaban udara di dalam lemari pengering. Rangkaian sensor temperatur dan kelembaban udara terdiri dari sebuah sensor SHT 11 dan resistor variabel 50k sebagai external pull-up resistor. Sensor SHT 11 berbentuk chip yang menghasilkan output digital yang telah terkalibrasi, seperti pada Gambar 3.

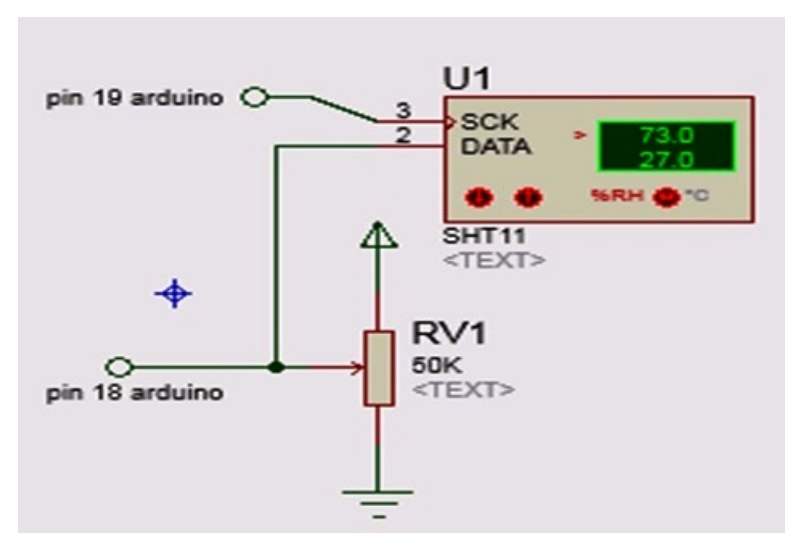

Gambar 3: Rangkaian sensor SHT 11.

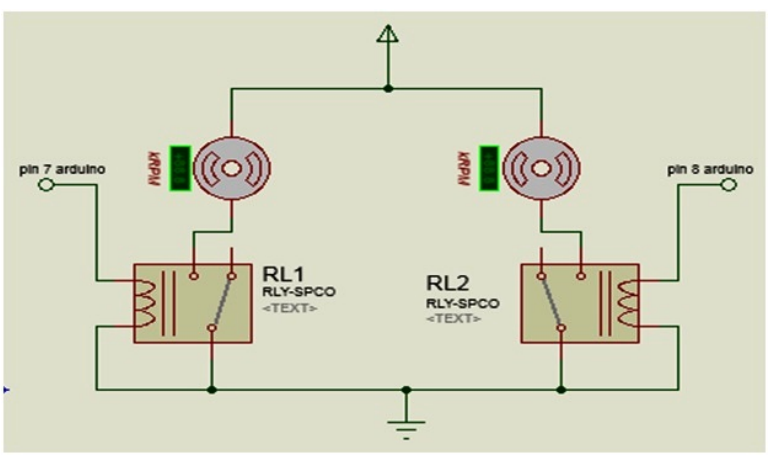

Gambar 4: Rangkaian relay.

\section{Pembuatan rangkaian relay sebagai saklar otomatis}

Selama proses pengeringan berlangsung temperatur dan kelembaban udara, lemari pengering harus dijaga sesuai dengan ketentuan yang standar. Untuk itu diperlukan komponen tambahan yakni berupa exhaust dan blower untuk menjaga temperatur dan kelembaban udara di dalam lemari pengering yang bekerja secara otomatis. Komponen exhaust dan blower dihubungkan dengan relay dan mikrokontroler Arduino UNO yang telah diatur dengan set point tertentu sehingga dapat digunakan sebagai saklar otomatis, seperti pada Gambar 4.

\section{Pembuatan rangkaian LCD graphic}

Selama proses pengeringan berlangsung diperlukan sebuah komponen yang dapat menampilkan hasil pengukuran temperatur dan kelembaban udara di dalam lemari pengering, sehingga perubahan temperatur dan kelembaban udara di dalam lemari pengering dapat teramati. Jenis LCD yang digunakan ialah graphic LCD ukuran $20 \times 4$ karakter, seperti pada Gambar 5 .

Prosedur pengambilan data dilakukan ialah sebagai berikut:

1. Menyusun setiap komponen seperti Gambar 6.

2. Mengukur massa benih padi mula-mula dengan timbangan digital sebanyak $500 \mathrm{~g}$ pada tiap rak.

3. Mengukur kadar air benih padi mula-mula dengan grain moisture meter. 


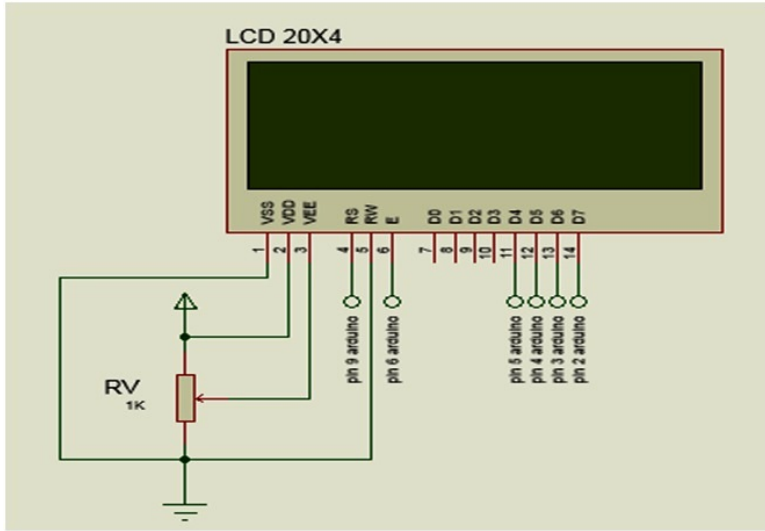

Gambar 5: Rangkaian LCD.

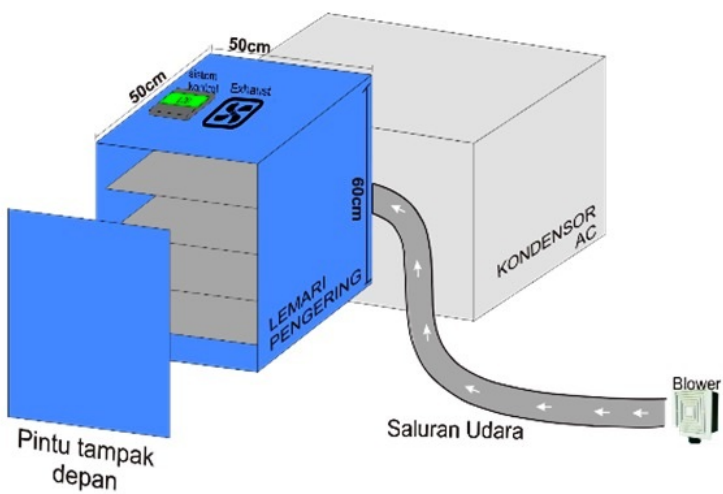

Gambar 6: Set up alat.

4. Meletakkan benih padi pada tiap rak dengan ketebalan sama.

5. Sambungkan port vec rangkaian dengan sumber listrik PLN.

6. Menyalakan $\mathrm{AC}$ dengan temperatur $16^{\circ} \mathrm{C}$ (3 jam kemudian).

7. Selanjutnya dilakukan pengamatan setiap 1 jam sekali dengan mengukur temperatur dan kelembaban udara di dalam lemari pengering serta kadar air dan massa benih hingga diperoleh kadar air $11 \%$.

\section{HASIL DAN DISKUSI}

\section{Hasil pengujian SHT 11}

Pengujian sensitivitas sensor dilakuakan dengan menggunakan hair dryer di ruang terbuka dan kalibrator yang digunakan ialah anymeter tipe FM-7903. Pengujian pada sensor meliputi pengujian karakteristik histerisis, linearitas dan akurasi sensor.

Untuk menentukan stabilitas sensor yang telah dibuat maka diperlukan pengujian histerisis yakni dengan cara melakukan pengukuran temperatur dan kelembaban pada saat dinaikkan

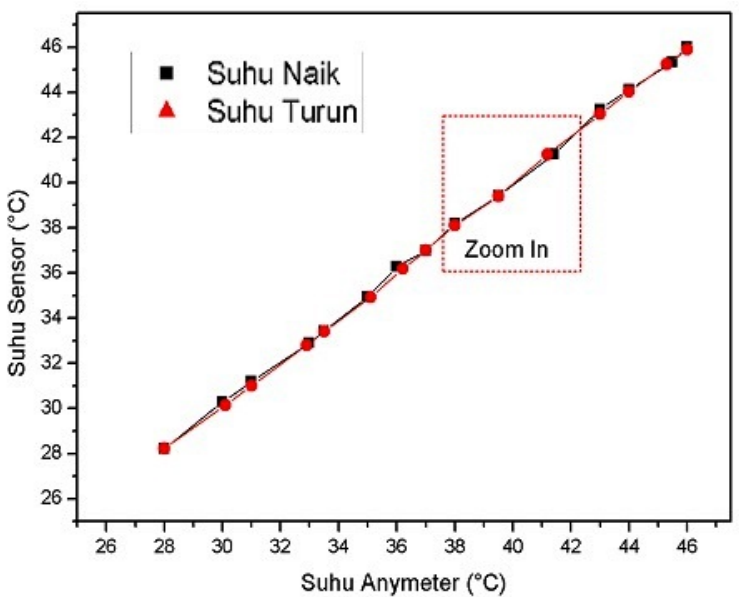

(a) Sensor temperatur

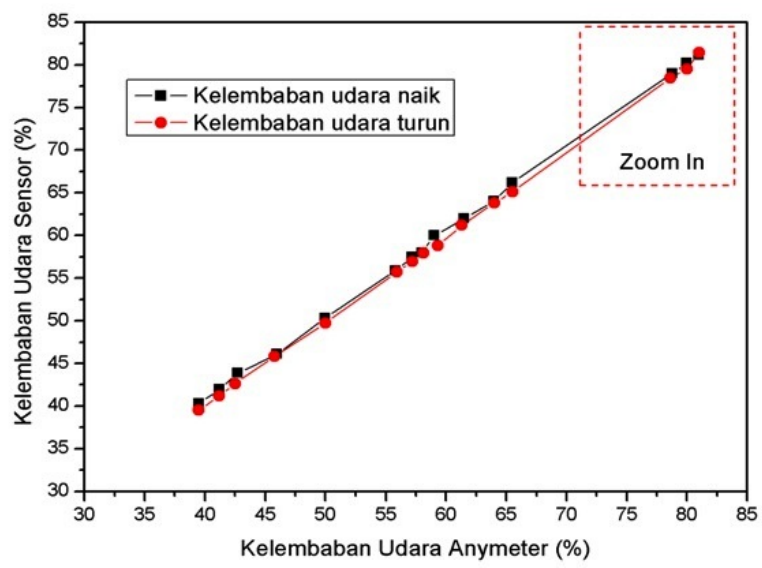

(b) Sensor kelembaban udara

Gambar 7: Hasil pengujian histerisis.

dan diturunkan. Stabilitas sensor dapat diamati dari hasil kurva pada Gambar 7 sampai dengan Gambar 9.

Kurva histerisis pada Gambar 7 terlihat berhimpit pada hasil pengukuran temperatur dan kelembaban udara saat dinaikkan dan diturunkan. Berdasarkan perhitungan didapatkan histerisis pengukuran temperatur terbesar adalah $0,435 \%$ FSO pada temperatur $28^{\circ} \mathrm{C}$.

Sedangkan hasil histerisis pengukuran kelembaban udara terbesar adalah $0.333 \%$ FSO pada kelembaban udara $81 \%$. Kurva linearitas sensor ditunjukkan oleh Gambar 8, dimana nilai linearitas terdiri dari dua yakni nilai $(+)$ yang menyatakan titik linearitas berada di bawah grafik linearitas best fit sedangkan nilai (-) berada di atas grafik linearitas best fit.

Linearitas untuk sensor temperatur yang digunakan yakni $-08,92 \%$ FSO pada $28^{\circ} \mathrm{C}$ dan $0,316 \%$ FSO pada $35,1^{\circ} \mathrm{C}$. Linearitas untuk sensor kelembaban udara yang digunakan yakni $-1,471 \%$ FSO pada $42,7 \%$ dan $0,455 \%$ FSO pada $59,3 \%$.

Pengujian akurasi sensor digunakan untuk mengetahui besar kecilnya kesalahan dari data yang dihasilkan. Gambar 


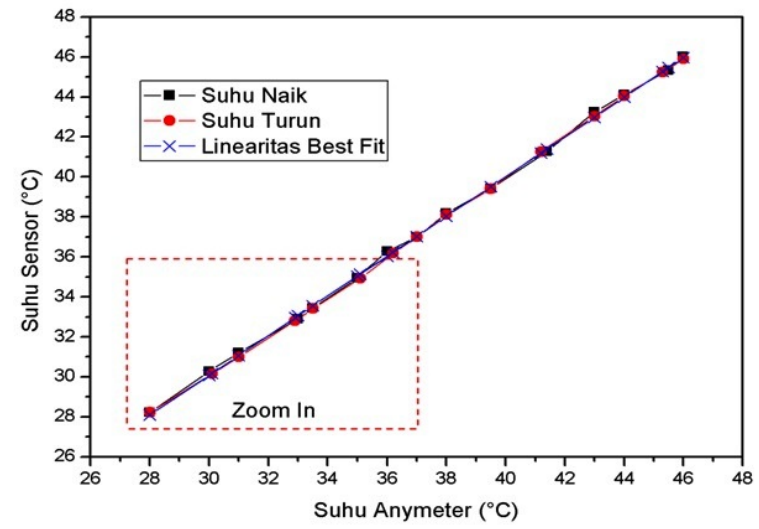

(a) Sensor temperatur

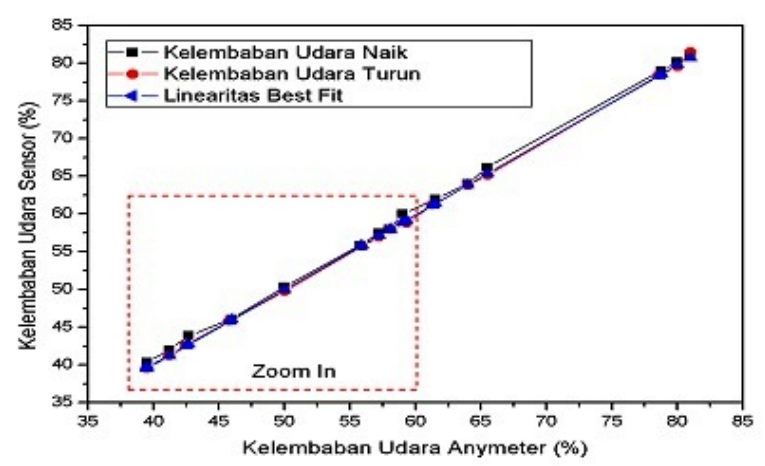

(b) Sensor kelembaban udara

Gambar 8: Hasil pengujian linearitas.

9 menunjukkan sensor temperatur memiliki ketidakakuratan sebesar $0,391 \%$ FSO pada 35,1C dan 0,005\% Reading pada $35,1^{\circ} \mathrm{C}$. Sedangkan sensor kelembaban udara memiliki ketidakakuratan maksimum sebesar $0,617 \%$ FSO pada $59,3 \%$ dan $0,008 \%$ Reading pada $59,3 \%$.

Berdasarkan ketiga pengujian karakteristik sensor dapat disimpulkan bahwa sensor SHT 11 yang diimplementasikan pada penelitian ini memiliki kemampuan yang baik dalam pengukuran temperatur dan kelembaban udara. Hasil pembacaan sensor kemudian dihubungkan dengan modul LCD untuk menampilkan hasil pengukuran sensor. Selanjutnya, untuk mempermudah kerja sistem digunakan adaptor $12 \mathrm{~V}$. Alat ini berfungsi untuk menurunkan tegangan PLN sebesar 220 volt AC menjadi 12 volt DC sebagai sumberdaya bagi mikrokontroler dan rangkaian lainnya.

\section{Hasil pengujian lemari pengering}

Pengujian dilakukan untuk mengetahui karakteristik panas buang kondensor AC yang masuk ke dalam lemari pengering. Besaran yang diukur selama pengujian ialah temperatur dan kelembaban udara. Posisi sensor ditempatkanpada jarak 20 $\mathrm{cm}$ didepan kondensor. Variasi setpoint temperatur AC yang digunakan ialah $16^{\circ} \mathrm{C}, 18^{\circ} \mathrm{C}$ dan $20^{\circ} \mathrm{C}$.

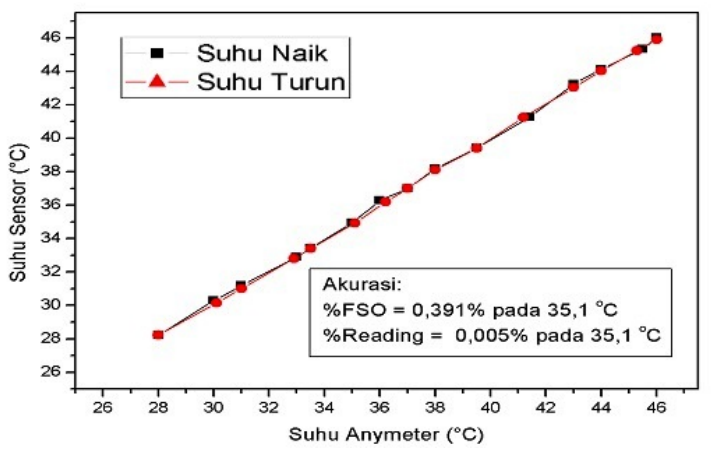

(a) Sensor temperatur

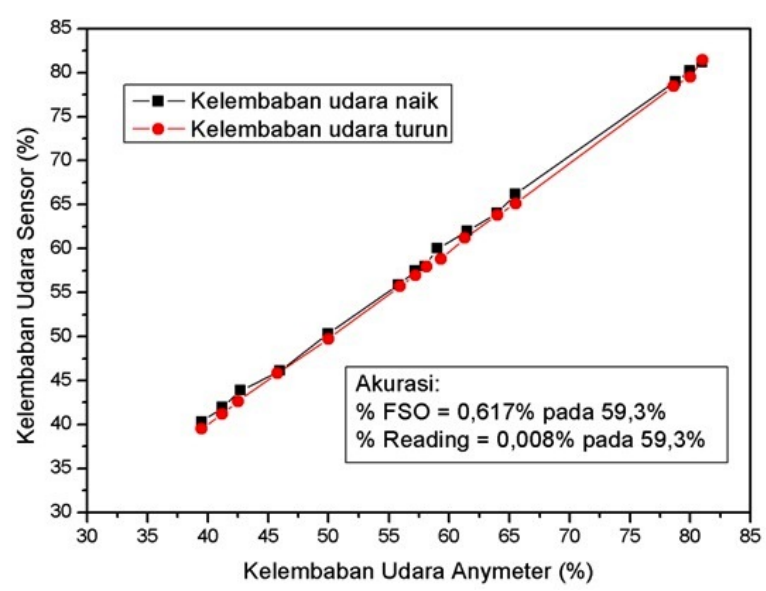

(b) Sensor kelembaban udara

Gambar 9: Hasil pengujian akurasi.

Pada Gambar 10 menunjukkan hasil pengukuran temperatur yang terekam oleh SD card. Rentang pengukuran temperatur dan kelembaban udara yang diperoleh ialah $33,52-38,69^{\circ} \mathrm{C}$ dan 48,61-65,24\%. Penentuan setting point temperatur AC mempengaruhi temperatur dan kelembaban udara yang dihasilkan kondensor. Set point temperature AC berbanding terbalik dengan temperatur dan berbanding lurus dengan kelembaban udara yang dihasilkan kondensor. Pengujian selanjutnya dilakukan untuk mengukur temperatur dan kelembaban udara di dalam lemari. Setting point temperatur $\mathrm{AC}$ yang dipilih ialah $16^{\circ} \mathrm{C}$ karena berdasarkan pengujian sebelumnya pada keadaan tersebut dapat menghasilkan temperatur paling tinggi.

Pada Gambar 11, kenaikan dan penurunan temperatur terjadi secara periodik dengan hasil yang merata. Temperatur maksimal yang dicapai ialah $46,42^{\circ} \mathrm{C}$, sedangkan kebutuhan temperatur lemari pada proses pengeringan yang diterapkan maksimum sebesar $43^{\circ} \mathrm{C}$. Agar dapat mempertahankan keadaan temperatur dan kelembaban udara dalam lemari pengering selalu sesuai dengan ketentuan pengeringan biji padi maka dibutuhkan pembuatan sistem kontrol yang tepat.

\section{Hasil pengujian pengeringan benih padi}

Secara garis besar ketentuan pengeringan benih padi ialah 


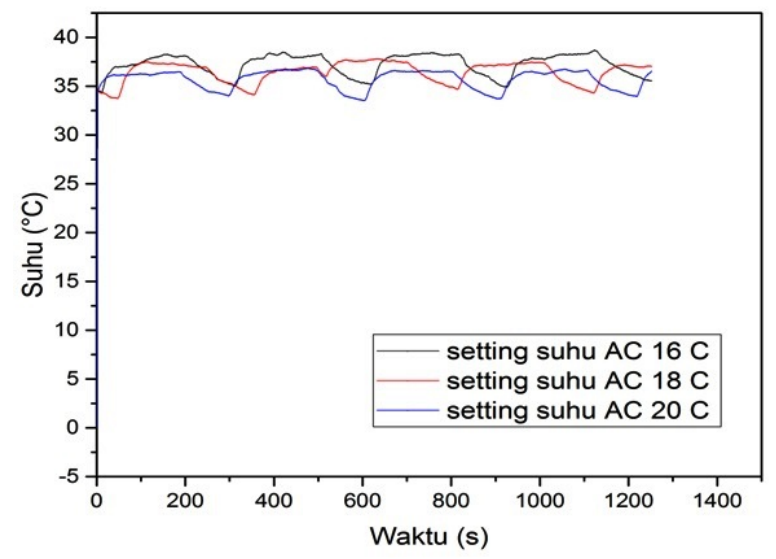

(a)

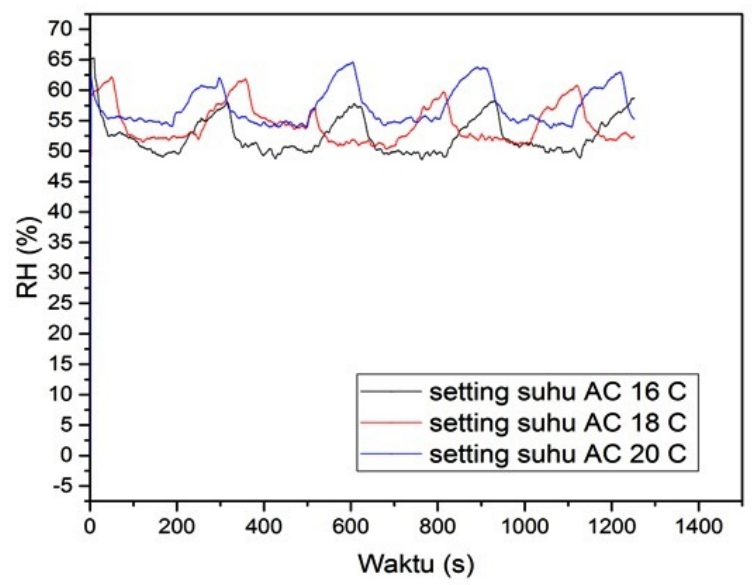

(b)

Gambar 10: Pengujian dengan variasi setting point temperatur AC (a) grafik hubungan perubahan temperatur dan waktu (b) grafik hubungan perubahan kelembaban udara dan waktu.

diawali dengan temperatur rendah di bawah $32^{\circ} \mathrm{C}$ selama 3 jam. Kemudian ditingkatkan maksimal $43^{\circ} \mathrm{C}$ dan diakhiri saat kadar air berada mencapai angka $12-10 \%$. Data hasil pengamatan kemudian diolah sehingga dapat ditampilkan dalam bentuk grafik seperti ditunjukkan dalam Gambar 11.

Pada Gambar 12 dapat dilihat proses pengeringan berlangsung selama 10 jam hingga kadar air akhir benih mencapai $11 \%$. Benih padi mengalami penyusutan kadar air sebesar $7,5 \%$. Sedangkan penyusutan massa sebesar 45,13 gram pada setiap rak. Perpindahan panas terjadi secara konveksi di udara, konveksi paksa dengan permukaan tumpukan padi, dan konduksi antara rak dan benih padi di atasnya. Udara panas yang keluar dari konensor AC memiliki kecepatan tertentu karena dorongan dari kipas propeler yang terdapat pada kondensor AC. Sehingga udara panas tersebut dapat mengalir pada seluruh ruangan dalam lemari pengering dalam bentuk radial. Saat udara panas dari kondensor bersinggungan dengan udara yang lebih dingin di dalam lemari maka temperatur di dalam lemari akan naik. Temperatur udara yang terus naik dan melewati permukaan tumpukan padi akan

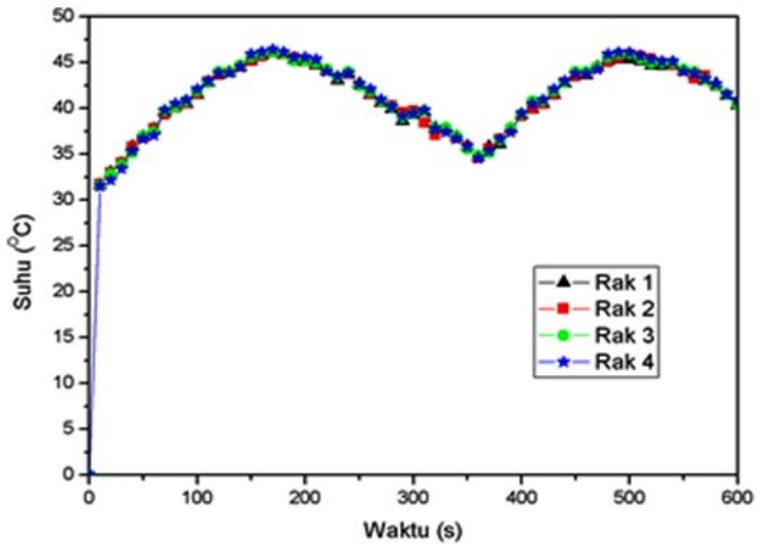

Gambar 11: Grafik hubungan perubahan temperatur dan waktu dengan variasi rak pada lemari pengering.

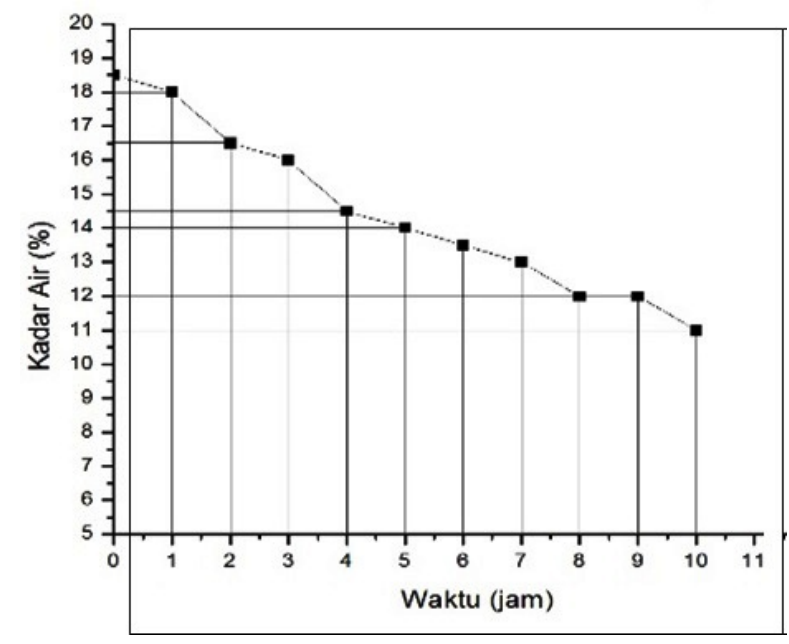

Gambar 12: Grafik penurunan kadar air benih padi terhadap waktu.

membuat temperatur di bagian terluar benih padi lebih tinggi daripada lapisan dibawahnya. Kenaikan temperatur lapisan benih padi hingga mencapai titik didih air yang terkandung didalamnya akan menguapkan air tersebut dan mengeluarkannya melewati pori-pori biji. Selain itu bahan rak digunakan terbuat dari alumunium merupakan konduktor panas yang baik sehingga dapat membantu proses pengeringan dengan adanya pemanasan secara konduksi dari permukaan bawah tumpukan padi. Proses ini akan sangat menguntungkan karena akan mempercepat dan meratakan proses penurunan kadar air benih padi.

Pada Gambar 13 dapat dilihat kerja sistem kontrol yang diterapkan pada lemari pengering. Pada grafik tersebut terlihat sistem dapat bekerja sesuai ketentuan pengeringan padi yang didasarkan pada penelitian oleh Balai Besar Penelitian Tanaman Padi. Temperatur dalam lemari pengering berhasil diatur sesuai standar yang ditentukan.

Kelembaban udara dalam lemari dapat dipertahankan di- 


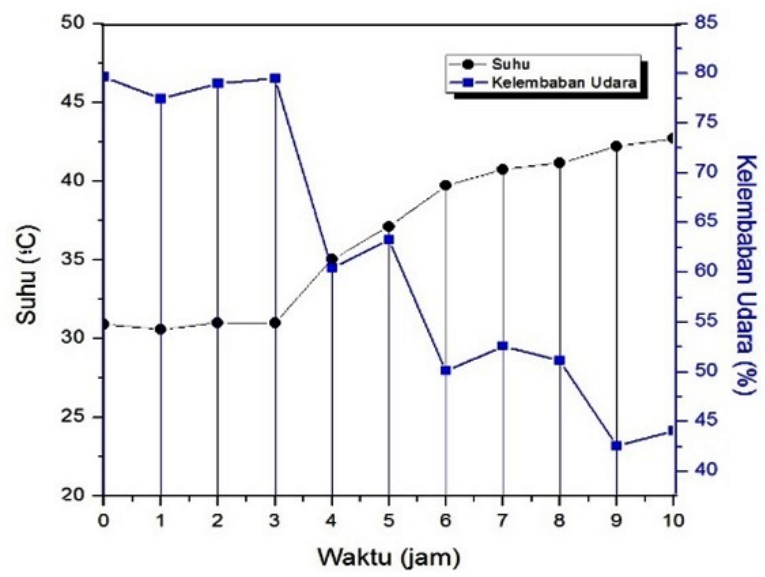

Gambar 13: Grafik hubungan temperatur pengeringan terhadap kelembaban udara lemari pengering. atas $45 \%$ hingga 8 jam proses pengeringan. Pada 2 jam terakhir kelembaban udara dalam lemari pengering berada pada rentang 42,55-44,08\%, hal ini menunjukkan kemampuan blower yang digunakan untuk mengatur kelembaban udara perlu sedikit ditingkatkan.

\section{SIMPULAN}

Berdasarkan hasil penelitian ini, dapat ditarik kesimpulan bahwa lemari pengering benih padi dengan memanfaatkan sumber udara panas dari kondensor AC kapasitas 3/4 pk yang telah berhasil dibuat berjenis tray dryer dengan kapasitas $2 \mathrm{~kg}$. Pengaturan temperatur menggunakan exhaust bekerja dengan baik sedangkan pengaturan kelembaban udara menggunakan blower dapat mempertahankan nilai kelembaban udara hingga diatas $42,55 \%$.
[1] BPTP Balitbangtan NTB, Teknologi Pengeringan Gabah, 2011 http: //www.ntb.litbang.pertanian.go.id (diakses pada 19 juli 2016 pukul $16.00 \mathrm{WIB}$ )

[2] D.E. Rahmanto, I.D.M. Subrata, Sutrisno, Pemanfaatan Panas Kondensor AC untuk Pengeringan BahanPangan: Studi Kasus Pengeringan Chips Kentang, Prosiding Seminar Nasional PERTETA, Jember, 21-22 Juli, 2011.

[3] U.S. Nugraha, dkk., Sistem Perbenihan Padi, Balai Besar Penelitian Tanaman Padi, 2009.

[4] UPTD Balai Pengawasan dan Sertifikasi Benih Tanaman Pangan \& Hortikultura. Laboratorium Penguji Mutu Benih, 2007.

[5] G. Taib, G. Said dan S. Wiraatmadja, Operasi Pengeringan pada Pengolahan Hasil Pertanian (PT. Melton Putera, Jakarta, 1987).
[6] S. Sudarmadji, B. Haryono dan Suhardi, Analisa Bahan Makanan dan Pertanian (Liberty, Yogyakarta, s003).

[7] A. Goeritno, D.J. Nugroho, R. Yatim, Implementasi Sensor SHT11 untuk Pengkondisian Suhu dan Kelembaban Relatif Berbantuan Mikrokontroler, Prosiding Seminar Nasional Sains dan Teknologi, Fakultas Teknik Universitas Muhammadiyah Jakarta, 2014.

[8] Y. Novitaningtyas, Design and Fabrication of Online Monitoring of Temperature Humidity Measuring System and Carbon monoxide Detector and Sending Data Via SMS, Tesis, FisikaITS, Surabaya, 2009. 